\title{
Cellular Morphology of Form 2 Mycobacteria in Slide Culture
}

\author{
By ANNA CSILLAG \\ The Medical Research Council's Unit for Research on Drug Sensitivity in Tuberculosis, \\ Postgraduate Medical School of London, Ducane Road, London, W. 12
}

(Received 4 April 1962)

\begin{abstract}
SUMMARY
Form 2 of a strain of Mycobacterium tuberculosis var. hominis was isolated. The cellular morphology of this organism when growing in glycerol agar slide culture is described. The form 2 strain grew by the initial production of septate filaments which soon ramified as a result of pseudobranching. The filaments fragmented early into bacillary elements and much later into coccoid elements. Endospores were formed within some of the bacillary elements. The young cells were Gram negative and the older cells Gram positive. The cells were never acid-fast. Growth occurred in aerobic and anaerobic culture, but the morphological changes progressed more rapidly under anaerobic conditions. The strain has many characteristics also found in some members of the Actinomycetaceae; however there are also differences, the most important of which is endospore formation. Thus the strain cannot yet be classified.
\end{abstract}

\section{INTRODUCTION}

In a previous publication (Csillag, 1961), it was reported that rapidly growing organisms, which were not acid-fast, were obtained from cultures of mycobacteria (the majority of the strains were Mycobacterium tuberculosis) grown under special conditions, when these cultures were inoculated on plates of nutrient agar. The rapidly growing organisms, at the time of their isolation, were described as Gramnegative spore-bearing rods or as Gram-negative cocci often arranged in chains. It was therefore suggested that mycobacteria might be dimorphic in the same sense that some of the human pathogenic fungi are known to be dimorphic. The acid-fast mycobacteria, as usually described, were termed 'form 1' and the organisms obtained on nutrient agar were termed 'form 2'. Subsequently, form 2 organisms have been isolated from all of the 123 strains of $M$. tuberculosis examined. The form 2 organisms were similar in their main characteristics, though variations between strains occurred. The life cycle of one of the strains, selected at random, has now been studied in detail. Reported here is a description of the cell morphology of this strain when grown under undisturbed conditions in slide culture. This particular aspect of a complex life cycle was chosen, in part, because it may throw light on the taxonomic position of the strain, and in part because slide culture is an easy means of identifying form 2 organisms and of distinguishing them from contaminants. 


\section{METHODS}

Strain. The strain (I 1413) of Mycobacterium tuberculosis used was isolated from the sputum of a British patient with pulmonary tuberculosis. It was virulent in the guinea-pig, sensitive to isoniazid, streptomycin and $p$-aminosalicylic acid and produced nicotinic acid (Runyon, Selin \& Harris, 1959). The strain was maintained on Löwenstein-Jensen medium at $37^{\circ}$ for 5 months before the isolation of form 2 organisms was begun. (The strain is deposited in the National Collection of Type Cultures, Colindale Avenue, London, N.W. 9 as NCTC 10.280.)

Media. (1) The Löwenstein-Jensen medium used was without potato starch (Jensen, 1955); (2) nutrient broth was prepared from meat extract+peptone (Oxoid, No. 2, Oxo Ltd., London); (3) nutrient agar was made by adding $1 \cdot 4 \%$ (w/v) agar to the nutrient broth; (4) glycerol agar was prepared by adding $7 \%$ analytical grade glycerol to nutrient agar; (5) 7H-10 oleic acid-albumin agar (Cohn, Middlebrook \& Russell, 1959). All media were incubated at $37^{\circ}$ for 2-3 days before use, as a test of their sterility.

Isolation and maintenance of form 2 organisms. After preliminary purification of the form 1 strain on $7 \mathbf{H}-10$ medium plates, form 2 organisms were obtained, as previously described (Csillag, 1961), by subcultivation from growth on aerated Löwenstein-Jensen medium slopes to nutrient agar plates. The form 2 strain was purified twice by single colony selection from nutrient agar plates which had been incubated for 3 days at $37^{\circ}$. Nutrient agar slopes in screw-capped bottles were inoculated from colonies on the second plate. The slopes were incubated with loose caps at $37^{\circ}$ for 3 days until sporulation had occurred; the caps were then closed and the cultures maintained at room temperature. The strain was re-purified and sporulation allowed to occur every two months. At the start of the experiments to be described, the strain had been maintained for 12 months and the last subculture was one week old (the initial culture).

Preparation of slide cultures. A $1 \cdot 2 \times 4$ in., flat-bottomed specimen bottle, plugged with cotton-wool and containing a $3 \times 1 \mathrm{in}$. microscopic slide and $10 \mathrm{ml}$. glycerol agar, was autoclaved. The bottle was then allowed to cool in a sloped position, so that the slide was at right angles to the surface of the medium. All the slide cultures were prepared at the same time and from the same batch of medium. A standard inoculum, containing vegetative forms only was prepared for the slide cultures in the following manner. The initial culture was plated out on nutrient agar. After incubation at $37^{\circ}$ for $24 \mathrm{hr}$, a suspension was prepared by adding a single colony to a $\frac{1}{4} \mathrm{oz}$. screw-capped bottle containing $0.4 \mathrm{ml}$. sterile distilled water and glass beads; the bottle was then shaken by hand for a few seconds. The suspension consisted of Gram-negative rods, some containing endospores (Pl. 1, fig. 1). A loopful of the suspension was inoculated into a $\frac{1}{2}$ oz. screw-capped bottle containing $8 \mathrm{ml}$. nutrient broth which was shaken mechanically at $37^{\circ}$ for $6 \mathrm{hr}$. The culture was composed of Gram-variable, vegetative rods; neither endospores nor free spores were present (Pl. 1, fig. 2). A loopful of this culture was then inoculated on to the slide cultures along the line where the slide entered the medium, thus allowing the organism to grow first on to a thin layer of medium on the slide and then on to the glass surface of the slide. The plugs of the slide cultures incubated under aerobic conditions were covered with aluminium foil. The purity of the inoculum was 
checked by plating on nutrient agar, and uninoculated slide cultures were incubated as medium controls.

Investigation of slide cultures. Several slide cultures were incubated at $37^{\circ}$ either aerobically or anaerobically in a McIntosh \& Fildes jar, controlled with a Lucas semi-solid indicator. At intervals one of each of the two types of culture was examined and then discarded. The slide was removed with forceps, allowed to dry under an ultraviolet lamp and fixed with methanol for 5 min. The growth on the slide close to the bottom of the specimen tubes, where condensation water was usually present during incubation, was examined. Preparations were stained by the Gram and Ziehl-Neelsen methods as described by Csillag (1961). Staining with malachite green (1\% malachite green in $1 \%$ aqueous phenol, filtered before use) was done for $5 \mathrm{~min}$. Cell walls were stained by the tannic acid-crystal violet method (Bisset, 1955).

\section{RESULTS}

\section{Aerobic incubation}

Morphology under low-power magnification. In slide cultures incubated under aerobic conditions, the following changes occurred in the cell morphology of the form 2 organisms, as observed under a magnification of $\times 120$. At one day, long, narrow filaments were seen growing away from the junction of the slide and the medium. The filaments had short side branches (Pl. 1, fig. 3). At about 7 days, the primary filaments were considerably thicker, the side branches had elongated and further ramification had occurred (Pl. 1, fig. 4). For at least the next 5 weeks, the filaments continued to ramify over further areas of the slide. The younger filaments were narrow but increased in thickness with age. The filamentous arrangement was maintained until the completion of the experiment at 6 weeks.

Morphology under high-power magnification. Examination of the slide cultures under high-power magnification $(\times 960)$ yielded further information on the detail of cell morphology and on the mode of branching. The growing ends of the filaments were composed of multicellular strands, about $0 \cdot 8 \mu$ diameter, in which the crosswalls were only visible when stained with tannic acid-crystal violet (Pl. 1, fig. 5) or when the preparation was examined unstained by phase contrast. In Gramstained preparations Gram-negative segments alternated with unstained zones, so that the continuity of the filaments was not evident (Pl. 1, fig. 7, left-hand portion). Older portions of the filaments were composed of separate rods lying end to end but without continuity from cell to cell when observed in preparations stained by all four methods. This arrangement suggested that the cells originated by fragmentation of the younger multicellular filaments. The youngest branches were composed of a single strand of cells, but gradually bundles containing parallel strands appeared (Pl. 1, figs. 6, 7). Some of the strands lay so close together that it was difficult to distinguish individual cells (Pl. 1, fig. 6). The majority of the cells in younger branches were still Gram negative but occasionally contained Gram-positive granules (Pl. 1, fig. 6). In older strands an increasing proportion of the cells were uniformly Gram positive (Pl. 1, fig. 7). Gram-positive material could not be distinguished by Ziehl-Neelsen or malachite green staining, the cells stained evenly with malachite green and none of them was acid-fast. At from 7 to 17 days endospores appeared in some cells and free-lying spores were also seen (Pl. 1, 
fig. 8). In Gram stains the wall of the endospores was Gram-labile and the interior unstained; in Ziehl-Neelsen stains the wall was blue and the interior unstained, and the spores stained uniformly with malachite green.

The branching observed under low-power magnification proved to be pseudobranching when examined under the higher power. A cell lying in the outer strand of a bundle changed its direction of growth and produced a filament at an angle to the main bundle (Pl. 1, fig. 7). Further strands then grew, probably from the main bundle, to lie parallel to this new filament.

After about 6 weeks some of the cells lying in strands were seen to fragment into coccoid elements. This process occurred in only a few cells, particularly those in the lower part of the slide culture near the water of condensation. At first the cells containing the coccoid elements were faintly stained, but later they disappeared, leaving the coccoid bodies lying in chains, in pairs or singly (Pl. 1, fig. 9). While intracellular, the coccoid bodies varied in shape (spherical or oval), but they were always spherical when extracellular. In both situations they ranged from $\mathbf{0 . 5}$ $1 \cdot 0 \mu$ in diameter. Both the coccoid bodies and the cells were Gram positive, not acid-fast and stained by malachite green, but the coccoid bodies were stained more intensely.

Smear preparations. Smears taken from the junction of the slide and the agar surface invariably failed to show any filamentous arrangement, thus suggesting that the filaments were easily disintegrated. Predominantly Gram-negative rods were found in smears from young cultures and, with increasing age, there were also Gram-variable and Gram-positive rods present. Smears from the oldest cultures were composed of Gram-positive rods (some containing endospores), free lying spores and cocci, giving the impression of a mixture of different bacteria.

\section{Anaerobic incubation}

The sequence of changes described in slide cultures grown aerobically also occurred in slide cultures incubated anaerobically, though they took place more rapidly. In anaerobic culture the changes may be summarized as follows: (1) ramification occurred at about 1 day instead of at about 7 days (Pl. 1, fig. 10). (2) The change from Gram-negative to Gram-positive cells appeared earlier. (3) Fragmentation of the filaments into individual cells occurred earlier in younger cells. Furthermore, the majority of the cells then lost their filamentous arrangement and were arranged randomly on the slide. (4) Fragmentation into coccoid elements was seen within 14 days (Pl. 1, fig. 11); although occurring infrequently, it was found in a higher proportion of the cells than in aerobic culture. (5) The free coccoid elements continued to divide by binary fission to form diplococci, tetrads and sarcina-like configurations, in which the individual cocci varied considerably in size (Pl. 1, fig.12). This division of the liberated coccoid elements was never seen in aerobic cultures. (6) In making smears it was apparent that the majority of the growth occurred within and not on the surface of the glycerol-agar medium of the slide-cultures. 


\section{DISCUSSION}

The main characteristics of the organism described are the formation of a pseudobranching filament which rapidly fragments into bacillary elements, followed much later by fragmentation into coccoid elements. Similar characteristics are known to be the main features of some organisms classified in the Order Actinomycetales. Waksman \& Henrici (1943) included in this order three families: (1) Mycobacteriaceae;(2) Actinomycetaceae; (3)Streptomycetaceae. The family Actinomycetaceae is subdivided into two genera: (1) Actinomyces (anaerobic, microaerophilic); (2) Nocardia (aerobic). Members of the family Actinomycetaceae (Buchanan) are defined as organisms forming a vegetative branching mycelium which fragments into bacillary and coccoid elements (Henrici's Molds, 1947; Bergey's Manual, 1948; Waksman, 1959). The fragments have been termed oidiospores, arthrospores, segmentation spores or fragmentation spores by different authors; their shape and size is similar to rod-shaped and spherical bacteria (Waksman, 1959). These fragments continue to divide by transverse fission and, when smears are made, the arrangement of the mycelial fragments is disturbed and the smears appear to consist of ordinary, mixed bacteria (Henrici's Molds, 1947). When subcultured into a suitable fresh medium, the fragments germinate to form a new mycelium (Waksman, 1959). In some strains parallel bundles of filaments have been found (Baldacci, Gilardi \& Amici, 1956); Gram-positive granules have been seen in the Gram-negative cytoplasm of the cells of some species (Henrici's Molds, 1947).

Although there are many similarities between the characteristics of the strain described in the present paper and the characteristics of the Actinomycetaceae, certain differences are apparent. However, when account is taken of the more recent publications on the morphology of the Actinomycetaceae the differences are less substantial and can be summarized as follows. (1) True branching was not observed in the filaments of the strain. Bisset \& Moore (1949) showed that true branching, which occurs in the Streptomycetaceae, is not seen in the Actinomycetaceae and Bisset (1955) suggested that members of the Actinomycetaceae should not be regarded as forming true mycelia, but as being composed of a mass of separate, filamentous bacteria. (2) The present strain had cross-walls even in the youngest filaments, whereas the young substrate mycelium of the Actinomycetaceae is generally considered to be non-septate initially (Ørskov, 1923; Henrici's Molds, 1947). However, Bisset \& Moore (1949) showed, by using the tannic acid-crystal violet stain, that the filaments were really composed of numerous short cells. (3) The youngest cells of the present strain were Gram negative. Although the Actinomycetaceae are usually considered to be Gram positive, occasional Gramnegative strains have been reported (Waksman, 1959). (4) The method of formation of endospores by the present strain (Pl. 1, fig. 8) appears to differ from the description of spore formation in the Actinomycetaceae. (5) Fragmentation into coccoid elements occurred at about 42 days in aerobic culture and at about 14 days in anaerobic culture. The formation of coccoid fragmentation-spores in the Actinomycetaceae is usually complete in 1-3 days (Krassilnikov, 1959; Erikson, 1949). On the basis of the majority of the characteristics the present strain should be classified in the family Actinomycetaceae. However, the production of structures which morphologically resemble endospores appears to exclude this possibility. Endo- 
spore production suggests classification among the Bacillaceae, but the continued multiplication of the coccoid elements by binary fission renders this classification untenable. It will be shown in a later publication that all form 2 mycobacteria, as well as the present strain, produce coccal bodies under microaerophilic conditions and that these continue to multiply regularly. Only certain aspects of the morphology of a typical form 2 strain are described in the present publication. The final classification of the strain must depend on a fuller account of the life cycle.

There have been several claims that rapidly growing, not acid-fast, saphrophytic and extremely pleomorphic organisms, resembling species of the Actinomycetaceae, have been obtained from various strains of mycobacteria (Coppen-Jones, 1895; Dostal, 1910; Karwacki, 1930; Møllgaard, 1931; Vaudremer, 1931). Weissfeiler (1933), from his own experience and by reviewing the literature, supported the theory of earlier workers that the genus Mycobacterium is a true member of the Actinomycetaceae; it is not acid-fast in its saprophytic form and appears only in the form of an acid-fast rod when adapted to parasitic life. Weissfeiler claimed that the parasitic form reverted to the saprophytic form under the influence of factors such as the old age of the cultures, frequent subcultivation, media poor in nutriments and the presence of toxic agents. According to these views, the acid-fast form of Mycobacterium tuberculosis might be only a single stage in a more complex life cycle.

I wish to express my sincere thanks to Dr D. A. Mitchison for advice and help in carrying out this work. I am grateful to Mr B. Uncles for his careful technical assistance.

\section{REFERENCES}

Baldacci, E., Gilardi, E. \& Amici, A. M. (1956). Il ciclo di vite degli Attinomiceti osservato al microscopio elettronico. Giorn. Microbiol. 6, 512.

Bergey's Manual of Determinative Bacteriology (1948), 6th ed. p. 892. Ed. R. S. Breed, E. G. C. Murray \& A. P. Hitchens. London: Ballière, Tindall \& Cox.

Bisset, K. A. \& Moore, F. W. (1949). The relationship of certain branched Bacterial Genera. J. gen. Microbiol. 3, 387.

Bisset, K. A. (1955). The Cytology and Life-history of Bacteria, 2nd ed., pp. 12, 95, 96. Edinburgh and London: E. \& S. Livingstone Ltd.

Cohn, M. L., Middlebrook, G. \& Russell, W. F. (1959). Combined drug treatment of tuberculosis. J. clin. Invest. 38, 1349.

Coppen-Jones, A. (1895). Úber die Morphologie und systematische Stellung des Tuberkelpilzes und über die Kolbenbildung bei Actinomycose und Tuberkulose. Zbl. Bakt. (1. Orig.) 17, 70.

Csillag, A. (1961). Spore formation and 'Dimorphism' in the Mycobacteria. J. gen. Microbiol. 26, 97.

Dostal, H. (1910). Zur Stellung des Tuberkelbacillus im System der Micro-organismen. Wien. med. Wschr. 60, 2098.

ErIKson, D. (1949). Differentiation of the vegetative and sporogenous Phases of the Actinomycetes. 4. Partially acid-fast Proactinomycetes. J. gen. Microbiol. 3, 361.

Henrici's Molds, Yeasts and Actinomycetes (1947), 2nd ed. pp. 350, 355, 356, 364. Ed. by C. E. Skinner, C. W. Emmons \& H. M. Tsuchiya. London: Chapman \& Hall.

Jensen, K. A. (1955). Towards a standardisation of laboratory methods. 2nd report of the Subcommittee of laboratory methods of the International Union against Tuberculosis. Bull. int. Un. Tuberc. 25, 89.

KaRWACKI, L. (1930). Bacilles tuberculeux comme forme évolutive d'un Streptothrix. Zbl. Bakt. (1. Orig.) 119, 369. 


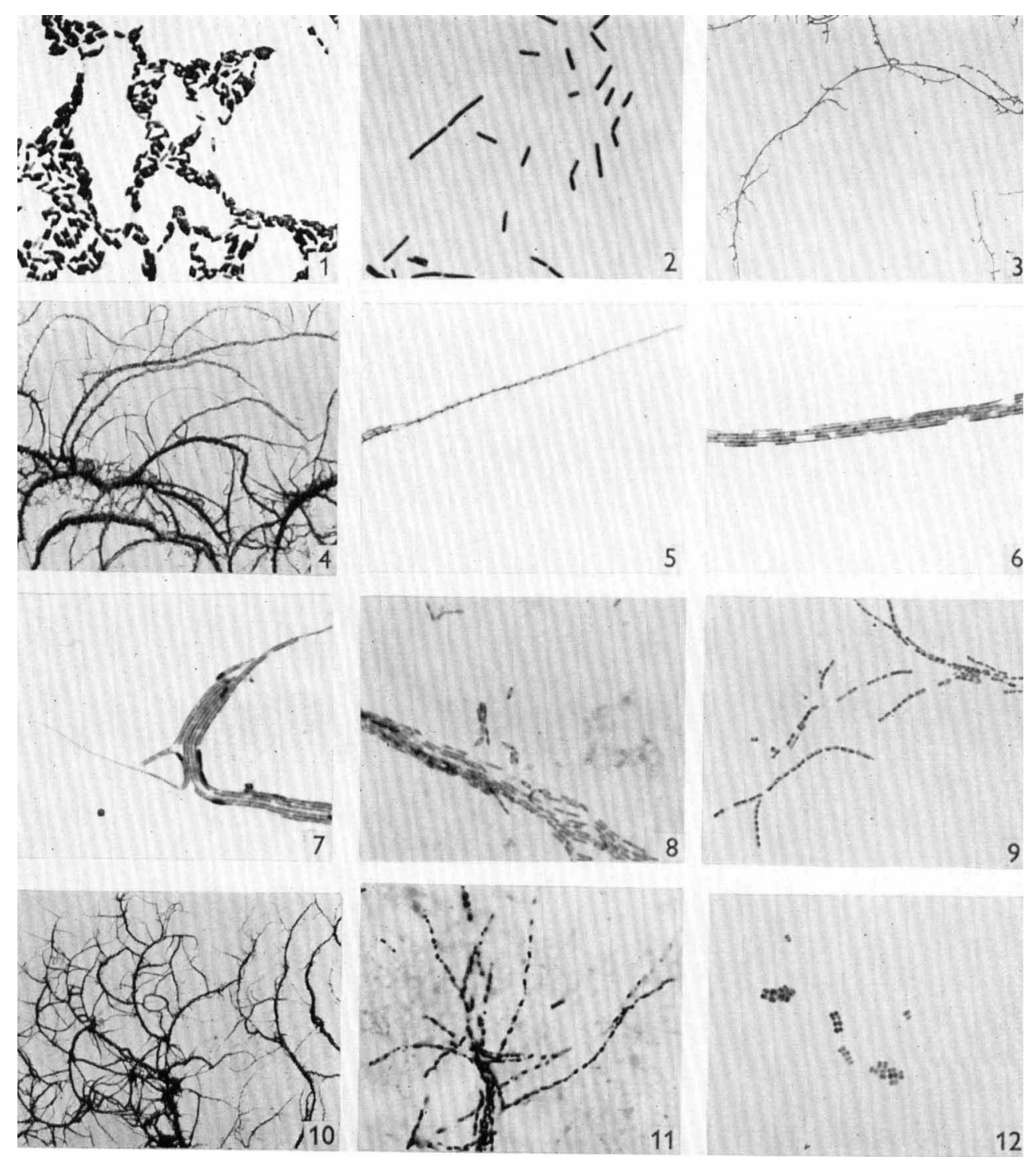
Krassilnikov, N. A. (1959). Diagnostik der Bakterien und Actinomyceten, pp. 119, 130, 138. Jena: Gustav Fischer Verlag.

MøllgaARD, H. (1931). Über den fraglichen Entwicklungscyclus des Tuberkelbacillus. Beitr. Klin. Tuberk. 77, 83.

Ørskov, J. (1923). Investigations into the morphology of the ray fungi. Kobenhavn: Levin \& Munksgaard.

Runyon, E. H., Selin, M. J. \& Harris, H. W. M. (1959). Distinguishing Mycobacteria by the niacin test. Amer. Rev. Tuberc. 79, 663.

Vaudremer, A. (1931). Études biologique du Bacille Tuberculeux. Les formes filtrantes. Beitr. Klin. Tuberk. 77, 16.

Waksman, S. A. \& Henrici, A. T. (1943). The nomenclature and classification of the actinomycetes. J. Bact. 46, 337 .

Waksman, S. A. (1959). The Actinomycetes, pp. 53, 65, 72, 79, 85, 89. London: Baillière, Tindall \& Cox.

Weissfeirer, J. (1933). Die Frage der nichtsäurefesten Formen des Tuberkulose Erregers. Zbl. Tbk. Forsch. 38, 449.

\section{EXPLANATION OF PLATE 1}

Figs. 1-12. Various stages in the development of a strain of Mycobacterium tuberculosis, form 2.

Fig. 1. Nutrient agar plate, 1 day, Gram stain, $\times 800$. Gram-negative rods, with and without endospores.

Fig. 2. Shaken nutrient broth culture $6 \mathrm{hr}$., Gram stain, $\times 800$. Gram-labile vegetative rods.

Figs. 3-9. Glycerol agar slide cultures, grown under aerobic conditions.

Fig. 3. 1 day, unstained, $\times 100$. Long filaments with short side branches.

Fig. 4. 7 days, Gram stain, $\times$ 100. Elongated side branches with further ramification; filaments thicker with increasing age.

Fig. 5. 4 days, cell-wall stain, $\times 800$. Growing ends composed of a single multicellular filament. Fig. 6. 4 days, Gram stain, $\times 800$. Very tight parallel bundles of strands; many of the Gramnegative cells contain Gram-positive granules; fragmentation into bacillary elements.

Fig. 7. 4 days, Gram stain, $\times 800$. Increasing proportion of the cells stain uniformly Gram positive; development of pseudobranching.

Fig. 8. 17 days, Gram stain, $\times 800$. Intracellular and free endospores.

Fig. 9. 42 days, Gram stain, $\times 800$. Fragmentation into coccoid elements, lying in chains, in pairs or singly.

Figs. 10-12. Glycerol agar slide cultures, grown under anaerobic conditions.

Fig. 10. 1 day, Gram stain, $\times 100$. Extensive ramification.

Fig. 11. 14 days, Gram stain, $\times 800$. Fragmentation into coccoid elements.

Fig. 12. 20 days, Gram stain, $\times 800$. Free coccoid elements dividing by binary fission to form diplococci, tetrads and sarcina-like configurations; sizes of coccoid elements very variable. 